\title{
The $\mathrm{J}$ \\ OURNA \\ AL \\ of \\ THE INSTITUTE
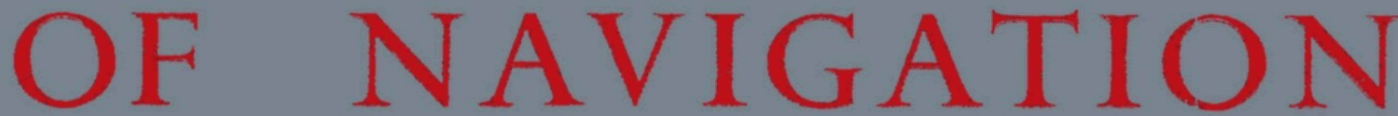

VOL. 19, NO. I

JANUARY

The Duke of Edinburgh's Lecture: The Continental Drift (Summary) P. M. S. BLACKETT

A Concept for Navigation and Communication using Satellites

R. E. ANDERSON

True Motion and Relative Motion

F. I. W YLIE

On the Frequency Distribution of Large Errorx

A. F. CROSSLEY

Subsurface Navigational Hazards

1. W. CHANSLOR

Height Measurement in Supersonic Aircraft

I-The Requirement

W. P. DAviES

II-Inertial Techniques in Height Measurement

R. WHALLEY

JII-Some Aspects of Pressure Measurement Techniques 68

B. CAPE

IV-Radio Altimetry

W. L. GARFIELD

$V$-Height Measurement from Doppler Navigation 35

G. E. BECK

23

33

41

56

6)

73

\$ 3

G. HAM MOND

Analysis of Long-Range Air Traftic Systems

Separation Standards-l

P. G. REICH

Costing Air Traffic Control Deviations

V. W. ATrwoolt

FORUM

Longitude without Time

F. CHICHESTER

The Impact of Radar on the Rule of the Rudd

P. Cissold

'The Sector Rule and the Collisiun Probleu'

3. García-Frías

The Three Stages of Radar Plotting

H. TOPLEY

The Essentials in Radar Presentation

P. HuGON

A Probability Distribution for a Time-varying Quantit.

D. A. LLOYD

A Survey of the Use of Astronomical Methods at Sida

D. MCG. BISSETt AND J. J. Evans

The Vinland Map

Reviews
88

99

106

109

312

115

117

$x+9$

122

124

126

THE INSTITUTE OF NAVIGATION
AT THE ROYAL GEOGRAPHICAL SOCIETY I KENSINGTON GORE LONDON SW 7

JOHN MURRAY (PUBLISHERS) LTD., so ALBEMARLE STREET, LONDON wı 


\title{
THE INSTITUTE OF NAVIGATION
}

\author{
Patron \\ H.R.H. PRINCE PHILIP DUKE OF EDINBURGH, K.G., к.T.
}

OFFICERS AND COUNCIL 1965-66

President

Rear Admiral E. G. Irving, С.в., О.в.E.

Vice-Presidents

Francis Chichester, C.B.E.

Air Vice Marshal W. E. Oulton, C.B., c.B.E., D.s.o., D.F.C.

Honorary Treasurer

Captain M. E. Butler Bowdon, O.B.E., R.N.

Chairman of the Technical Committee

G. E. Beck

Chairman of the Membership and Fellowship Committee

D. H. Sadler, O.B.E.

Council Members

Group Captain D. Bowwer, O.B.F., A.F.C.

Captain A. F. Dickson

Captain F. Ormonroyd, D.F.M.

Group Captain E. Fennessy, C.в.E.

D. M. Page

Commander C. E. N. Frankcom, R.N.R.

Commander G. V. Parmiter, M.N.(Ret.)

Captain W. L. Manson

C. Powell

A. Stratton

Executive Secretary : M. W. Richey

\section{The Journal of the Institute of Navigation}

THE Journal is published quarterly by the Institute and is edited by $M$. W. Ricuey. It contains original papers contributing to the science of navigation, including those presented at meetings of the Institute together with the ensuing discussion. In addition the journal includes a record of current navigational work, reviews of important books, and other matters of concern to those interested in navigation. The views expressed in the Journal are not necessarily those of the Institute, or of any organization or department to which the authors may belong.

The Joumal is free to all members of the Institute. It is sold to the public at twenty shillings per copy or, by subscription, at eighty-four shillings per annum (post free) and may be obtained through all booksellers and John Murray (Publishers) Ltd., 50 Albemarle Street, London Wr.

Contributions, which are welcomed from both members and non-members, should be addressed to the Editor.

Enquiries for advertising space should be addressed to the Institute offices.

The postal address of the Institute is:

The Institute of Navigation, at The Royal Geographical Society, 1. Kensington Gore, London $\mathrm{SW}_{7}$.

Telepione: Kensington 5021 


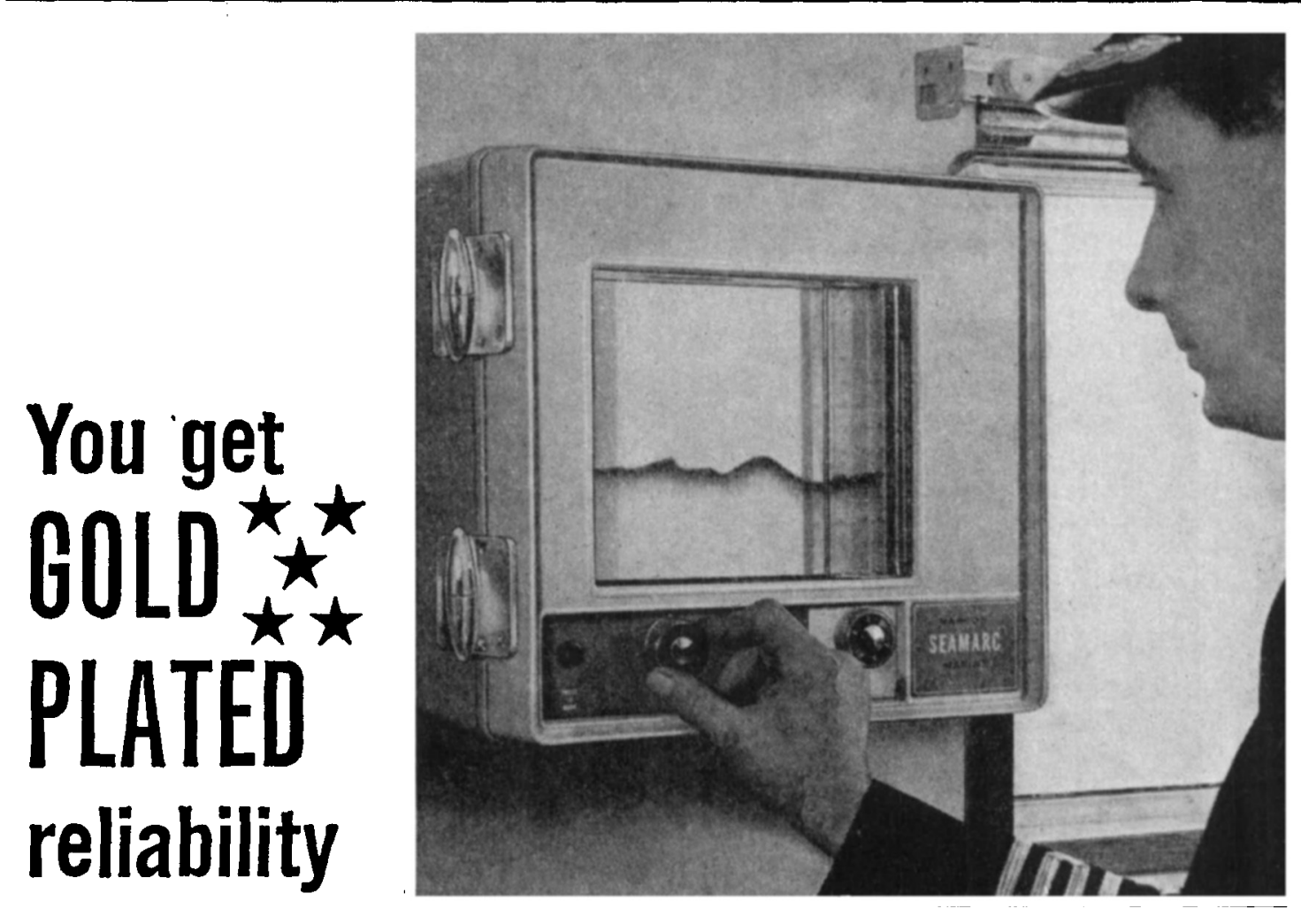

...WITH MARCONI MARINE'S NEW

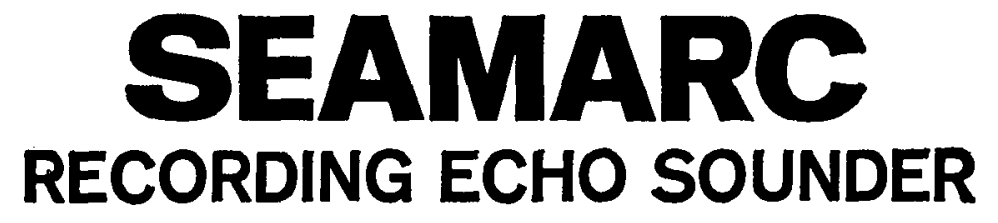

hailing reliability, high performance and tant readiness are outstanding features of the w 'Seamarc' fully-transistored echo sounder. aled-in-glass contacts are gold-plated and aranteed for a hundred million operations! eamarc' is simple to install and operate, and IAILABLE ON HIRE AT VERY ATTRACVE TERMS AS WELL AS FOR SALE.
Please ask for full technical particulars, or see the new 'Seamarc' at your nearest Marconi Marine depot.

* 4 ranges, 0-440 fathoms

* Extremely quiet operation

* Solid state circuitry

* Minimum power requirements from mains or batteries

\section{MARCONI MARINE}

aintain expert service facilities throughout the world

E MARCONI INTERNATIONAL MARINE COMPANY LIMITED,

ITTRA HOUSE - WESTWAY - CHELMSFORD - ESSEX TELEPHONE : CHELMSFORD 57201

0 at London and in all principal ports 


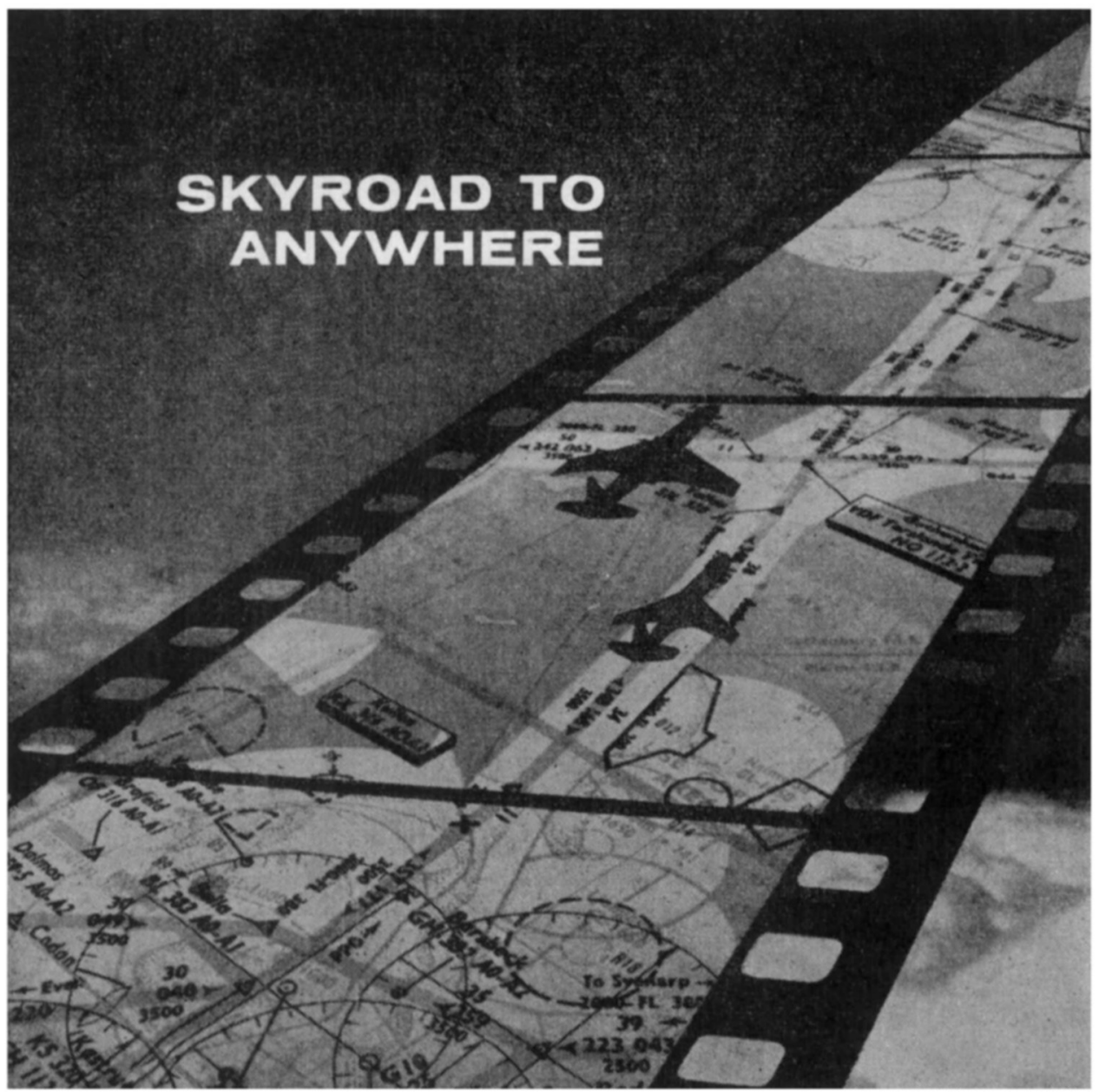

\section{The FERRANTI Moving Map Display}

...... The Ferranti Moving Map Display is designed to meet ICAO and Eurocontrol Association requirements for pictorial navigation displays for the aircraft of today and tomorrow.

The Ferranti Moving Map Display shows aircraft position and track continuously and automatically on optically projected film of aeronautical charts. The Display is simple, accurate, reliable-greatly reduces cockpit workload. Wide coverage is providedenough film can be stored to cover almost any airline operation in the world.

\section{FERRANTI \\ First into the Future}

FERRANTI LTD., FERRY ROAD, EDINBURGH 6

Telephone: DEAn 1211
The Ferranti Moving Map Display-a military version is now in production-can operate on outputs from inertial or Doppler navigation systems or on suitable rho-theta information.

The Ferranti Moving Map Display provides a skyroad to anywhere.

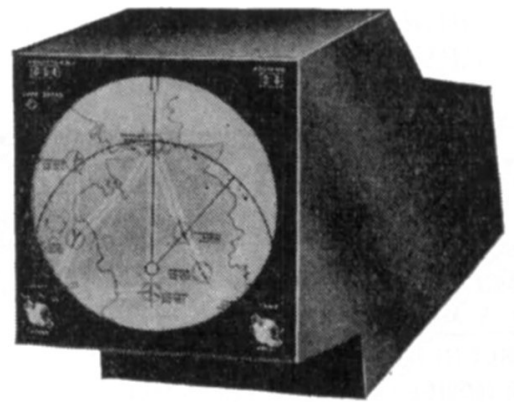




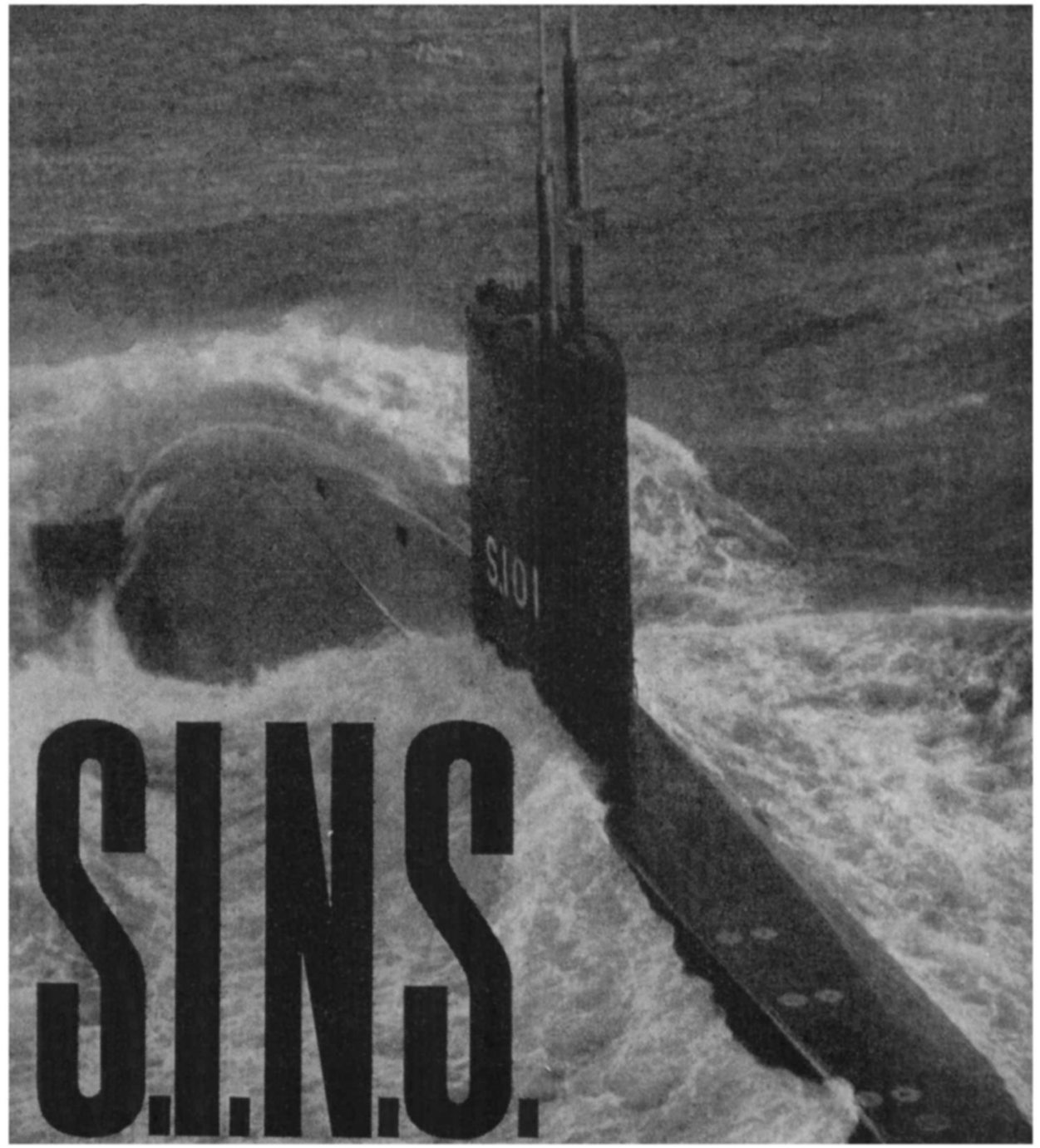

Crown copyright reservod

\section{FOR THE ROYAL NAVY}

Production of British Ships' Inertial Navigation Systems (B.I.N.S.) has been entrusted to Sperry, following the successful development of Admiralty equipment installed in H.M. Submarine DREADNOUGHT. Bperry's unrivalled experience of stable platforms and inertial navigation eystems was an important factor in their being chosen for the task.

g.I.N.S.enables ships of the Royal Navy to establigh their exact position without reference to extermal aids. Aircraft carriers, hunter-killer nuclear submarines, and the new County Olass Destroyers will all have British 8.I.N. B.

Bperry contribute extensively to the following Naval Projects:- CF.299 small ahip's gudded weapon; the BEASLUG ship-to-air missile; shipborne equipment for BEACAT, and an advanced system of gun-fire control.

\section{siffint INERTIIL NAVIGGTION SYSTEMS}

SPERAY GYROSCOPE COMPANY LTO., BRACKNELL, BERKS. PHONE BRACKNELL 13OT. 


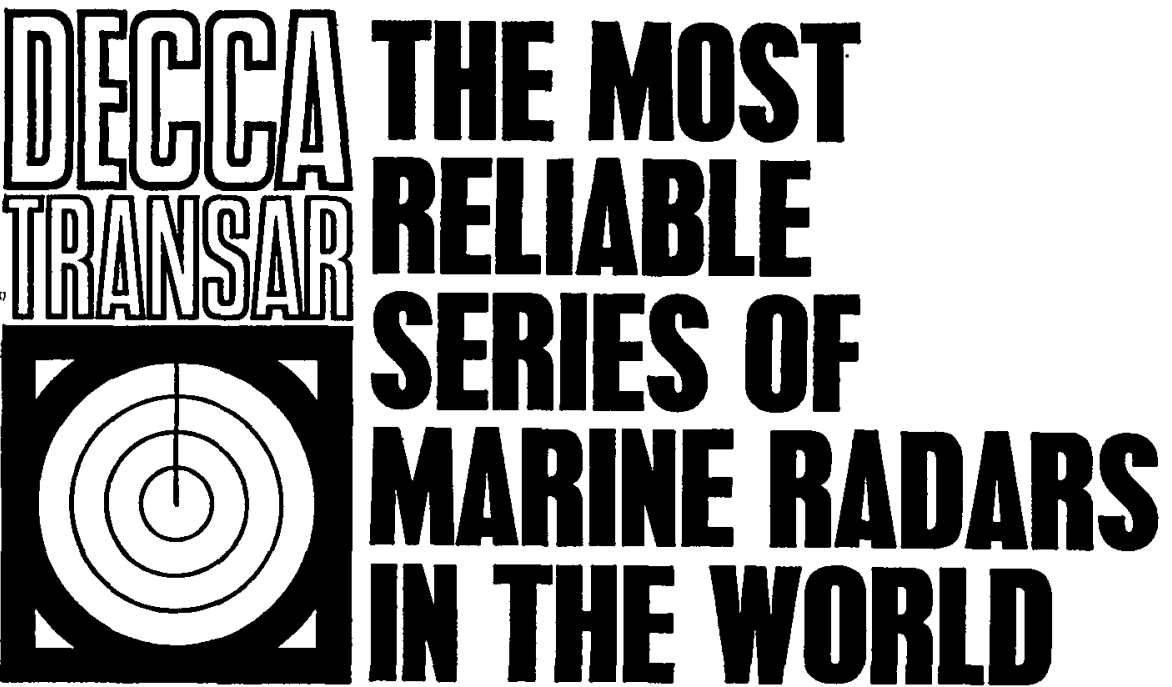

Decca TRANSAR is a series of transistorised marine radars which establishes a completely new standard of reliability for marine electronics. Searching tests are carried out at all stages of design and development, through extremes of heat, cold, humidity, vibration, pressure and shock-and this rigorous testing programme is continued after production to ensure that the high reliability and quality standards are maintained.

The 16 sets in the TRANSAR series all represent a careful integration of five basic elements: experience, design, manufacture, test and service. Decca possesses unparalleled strength in all of them and they are skilfully combined in the TRANSAR concept to bring shipowners the finest radar in the world.

There are five groups in the TRANSAR series corresponding to the main types of radar in service:

Low Cost Radar-6-in display, $\frac{1}{2}$ to $24 \mathrm{~nm}$ range; $3 \mathrm{~kW}$ transceiver; 4-ft aerial.

\section{9-in Relative Motion Radars -} 5 radars with 9-in displays, $\frac{1}{2}$ to $48 \mathrm{~nm}$ range; $10 \mathrm{~kW}$ or $25 \mathrm{~kW}$ transceivers; $4-\mathrm{ft}, 6-\mathrm{ft}$ or 9 -ft aerials. 12-in Relative Motion Radars4 radars with 12 -in displays, $\frac{1}{2}$ to $48 \mathrm{~nm}$ range; $10 \mathrm{~kW}$ or $25 \mathrm{~kW}$ transceivers; 6 -ft or 9-ft aerials.

High Definition Radars -2 radars with 12-in displays, $\frac{1}{4}$ to $24 \mathrm{~nm}$ range with off-centring: $10 \mathrm{~kW}$ transceiver; 6 - $\mathrm{ft}$ or 9-ft aerials.

True Motion Radars -4 radars with 12-in displays, $\frac{1}{2}$ to $48 \mathrm{~nm}$ range; $10 \mathrm{~kW}$ or $25 \mathrm{~kW}$ transceivers; 6-ft or 9-ft aerials.
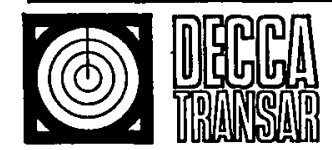

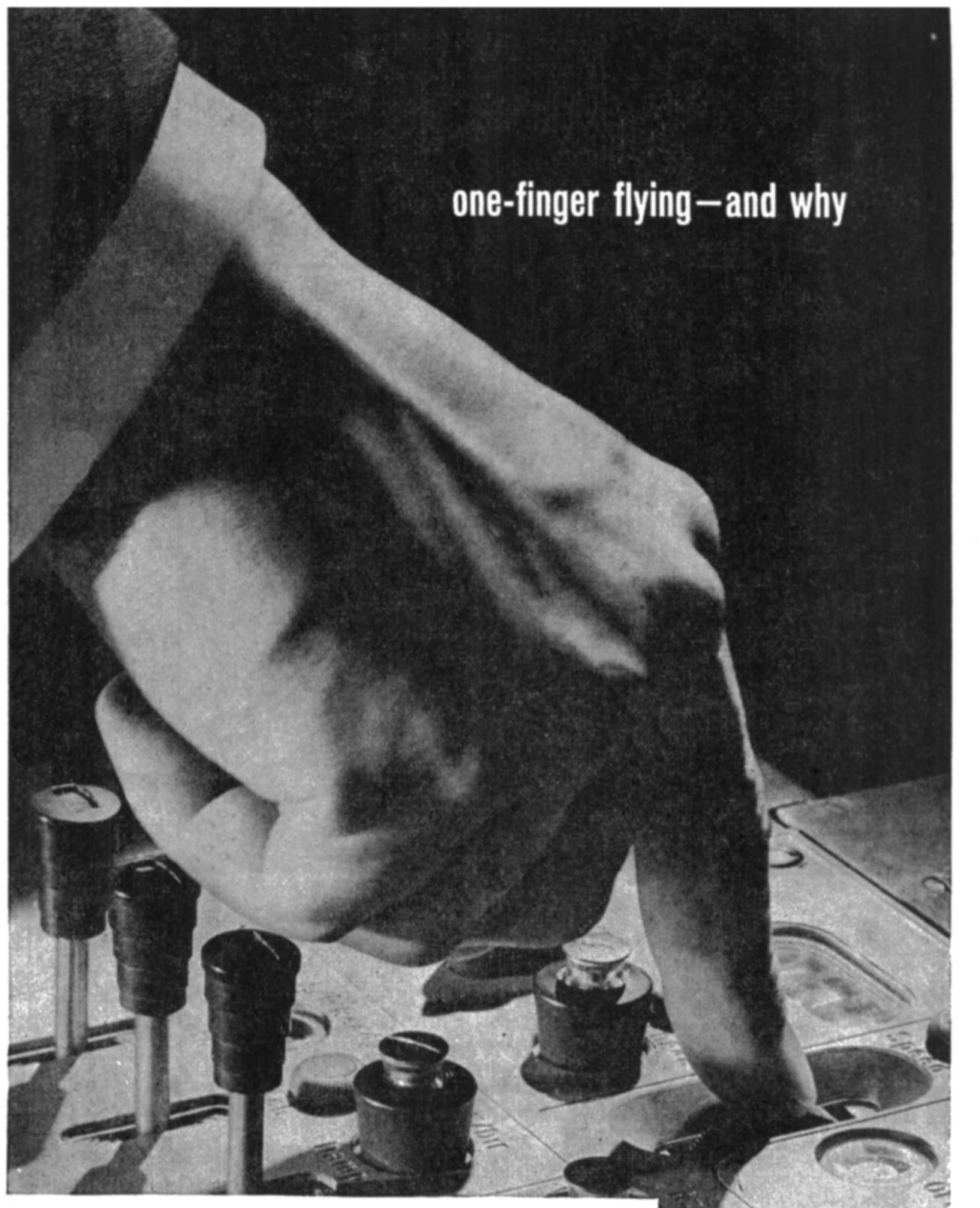

Acquiring height or airspeed is a one-finger exercise for the pilot of an aircraft - such as the Trident or the Belfast-which is equipped with Smiths SEP. 5 Flight Control System. By providing these and many other automatic facilities in their newgeneration flight systems, Smiths Industries not only deliver the pilot from mere drudgery. They free his attention, his skill and his judgement for undivided concentration on the decisionmaking which is his true responsibility. Smiths Industries systemisation enables the pilot to maintain continuous, total command.

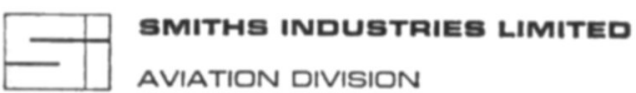

S. SAV.951 


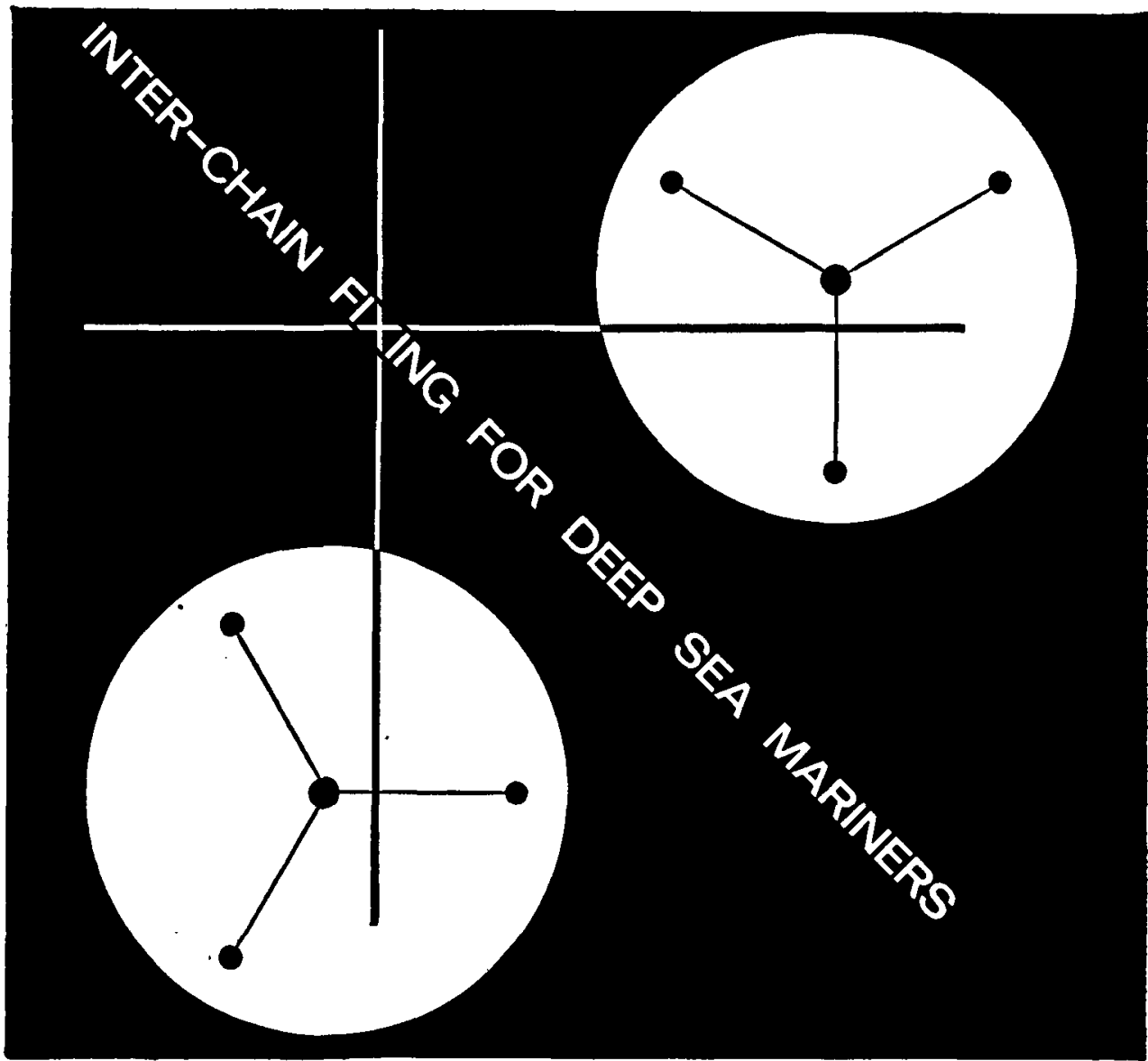

This technique, recently developed by Decca, substantially increases accuracy of the Decca fix at the outer limits of normal Decca coverage since the Mark 12 receiver and the Multipulse transmission system combine to give very reliable lane identification. This is facilitated by placing the chain selector switch on the indicator unit, thus permitting rapid chain selection.

\section{THE DECCA NAVIGATOR MK 12 MULTIPULSE}

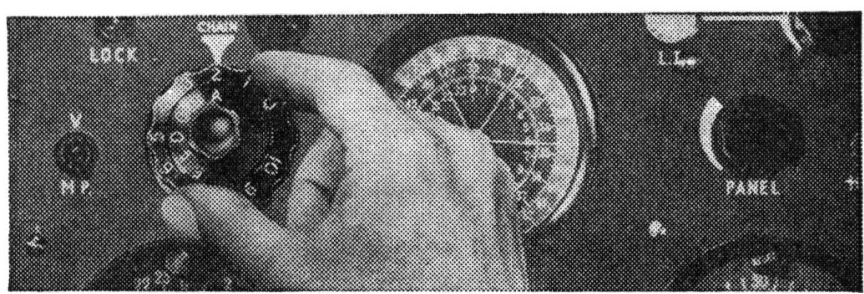

Charts for many areas overprinted with position lines from more than one Decca chain are now available. This new facility will be most useful to those using Decca at the longer ranges or requiring to make a landfall at the earliest opportunity. 


\section{Marconi AD560}

\section{proved in service \\ the most accurate and reliable civil doppler navigator in the world}

\section{$\triangle$ SIXTY SERIES}

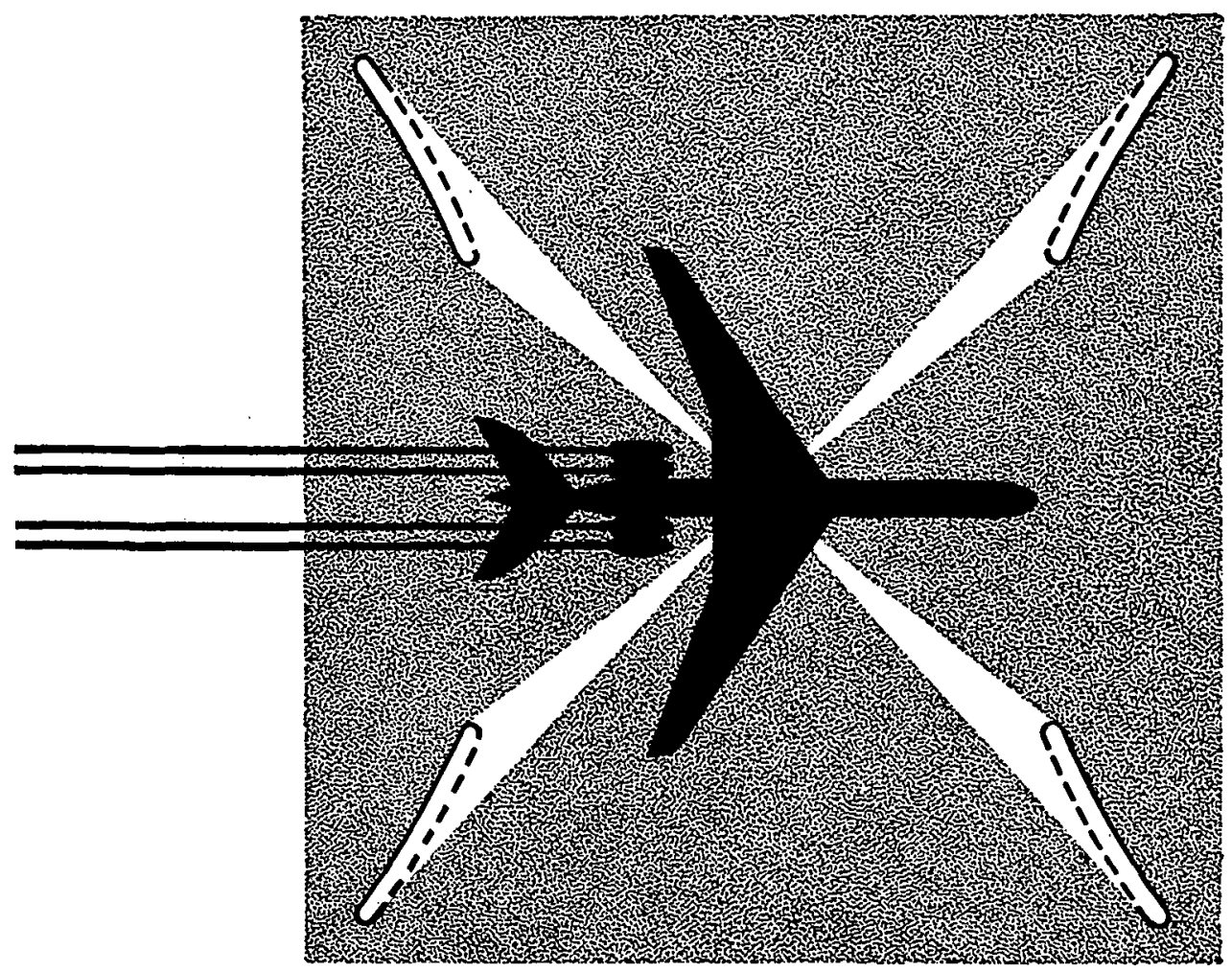

The Marconi AD560 doppler navigator will keep you on track and on time whether you are flying supersonic or subsonic over land or sea.

\section{Marconi airadio systems}

The Marconi Company Limited, Aeronautical Division, Basildon, Essex, England

LTOIAss 


\title{
THE INTERNATIONAL HYDROGRAPHIC BUREAU
}

Avenue Président J. F. Kennedy, MONACo

\author{
publishes
}

twice a year, in January and July, an English and French edition of

\section{THE INTERNATIONAL HYDROGRAPHIC REVIEW}

This publication contains articles of topical interest on hydrography, hydrographic surveying and related techniques.

Each volume contains an average of 160 pages, $18 \times 27 \mathrm{~cm}$, and numerous illustrations.

Price per number $\$ 5$ (U.S.) excluding postage.

Orders should be sent direct to the Bureau's Headquarters in Monaco, but payments can be made to the Bureau's account at Barclays Bank Ltd., Chief Foreign Branch, 168 Fenchurch Street, London, E.C.3.

A reduction of $30 \%$ on the price quoted is allowed to booksellers. The same reduction is granted to government offices and to naval or merchant marine officers of the Bureau's States Members, provided the order is sent direct to the Bureau. 


\section{'NAVIGATION,}

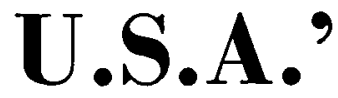

Navigation, the quarterly Journal of the American Institute of Navigation, is available to members of this Institute at a reduced subscription of $f_{1} 1$ a year. Volume 12, No. 3 (Autumn 1965), contains the following papers.

FROM SIMPLE QUADRANT TO SPACE SEXTANT

Saul Moskovity

PRECISE NAVIGATION REQUIREMENTS FOR HELICOPTERS AT SEA

V. Withington

A SHORT STUDY OF STATISTICS OF COLLISION BETWEEN MERCHANT VESSELS R. F. Riggs

TRUE MOTION COMPUTER AIDS MOVING TARGET IDENTIFICATION

David F. Sykes, Neil J. Jorgensen and Lt. Kenneth F. Cutler, U.S.C.G.

OPTICAL SYSTEM TO IMPROVE ACCURACY OF ASTRONOMICAL OBSERVATIONS Caplain G.P. Hadjilias, N.C., M.I.N.

ELECTRONICALLY STEERABLE ANTENNAS FOR SPACECRAFT-TO-SPACECRAFT COMMUNICATIONS

Dennis L. Backus

SPECIFICATION OF INERTIAI NAVIGATION ACCURACIES

Capt. Jefferson Z. A macker, U.S.A.F., and Lt. Francis J. Mason, U.S.A.F.

A SOLUTION OF THE BOUNDARY VALUE PROBLEM FOR SPACE TRAJECTORIES

John Graham Hartwell

THE INSTITUTE FILE

NOTES AND COMMENT

REVIEWS OF RECENT BOOKS.

\section{THE SOURCES OF THE NIIE EXPLORERS' MAPS}

\section{A.D. 1856-1891}

Reproductions of Early Maps-VIII

Ten collotype plates (two in colour) with pamphlet in portfolio, $21 \times 16 \frac{1}{2}$ inches.

Reproductions of manuscript maps by Nineteenth Century British explorers of Central Africa-Speke, Livingstone, and others.

Price 42s. plus postage 3s.

From the Office of the

ROYAL GEOGRAPHICAL SOCIETY I KERSINGTON GORE, LONDON, s.W.7.

\section{The Mariners' Highway Code} by Capt. D. R. Derrett THIS IS AN ENTIRELY NEW AP. PROACH TO THE OLD PROBLEM OF LEARNING 'RULE OF THE ROAD' AT SEA.

THE DISPLAY CARD AND COLOURED DISCS PROVIDED WITH THE BOOK ARE MODELS OF THOSE USED IN THE EXAMINATION CENTRES SO THAT THE BOOK CAN BE USED BOTH AS A SELF-EXAMINER AND FOR SHIP-BOARD EXAMINATIONS.

Section One contains the new International Regulations for preventing Collisions at Sea. Section Two contains extracts from the Admiralty Notices to Marlners; the Book of Merchant Shipping Notlces; the Admiralty List of Lights and the Public Health (Ships) Regulations. Section Three deals with the question of 'How is she heading? Section Four deals with the Uniform System of Buoyage, wreck marking and navigation in narrow channels.

78. 6d.

Order from your bookseller or THE MARITIME PRESS LTD., 13 Long Acre, London, W.C.2. 


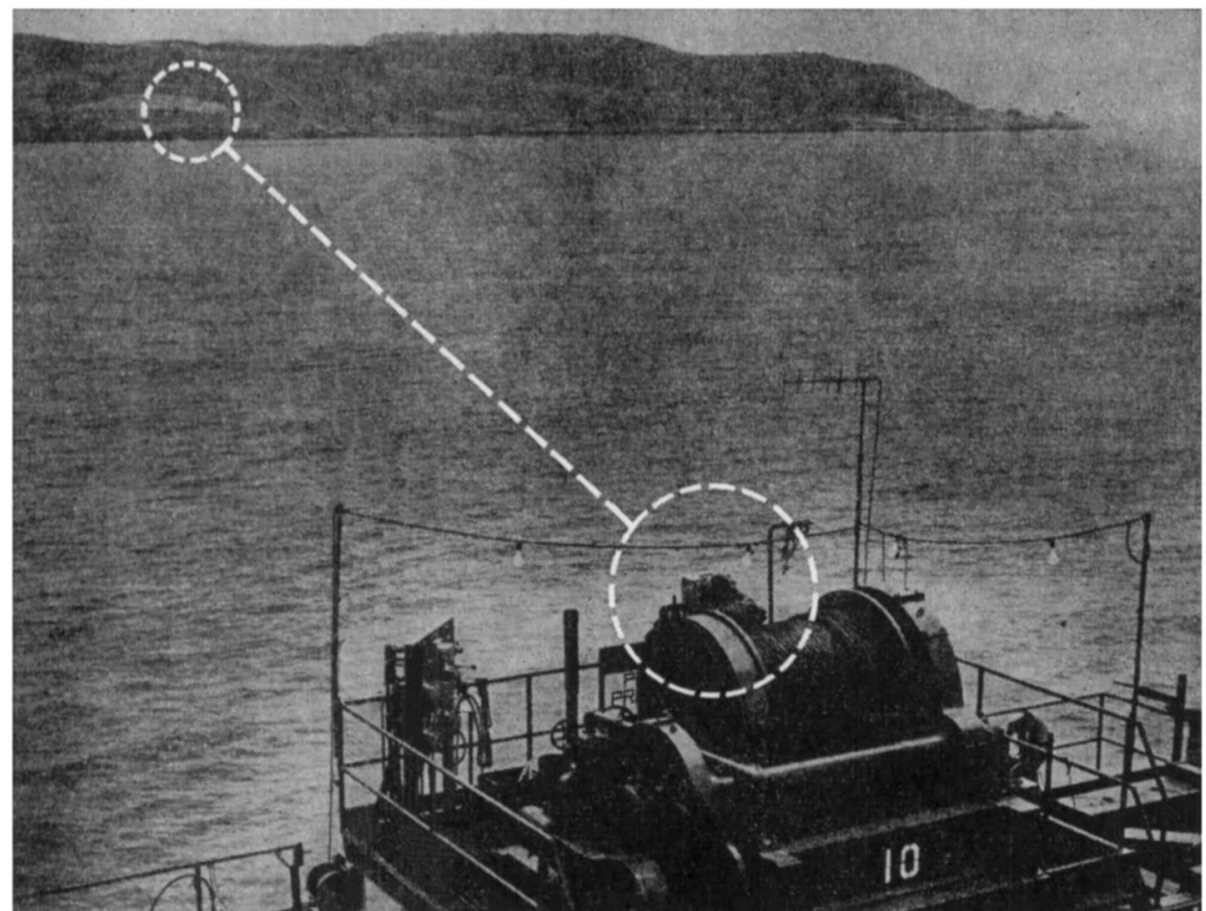

\section{Cubic Electrotape measures where chain and tape can't!}

Where other surveying methods are impossible ... Cubic Electrotape gives fast, accurate measurements. This precise electronic instrument measures distance across water or impassable terrain. Its range extends from a few feet to 30 miles.

Cubic DM-20 Electrotape Unit

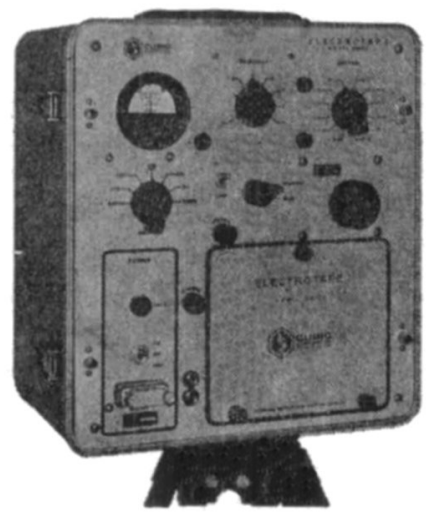

Time saving offshore uses include drilling site location, dredge positioning, oil exploration, and other stationary hydrographic and oceanographic surveys.

Simple operation...

Electrotape weighs only 24 pounds and is extremely simple to operate. Inexperienced personnel can be used, eliminating the need for costly stand-by electronics technicians.

\section{Easy financing ...}

Electrotape is available for sale, lease or rental. It quickly pays for itself in dollar savings!

Write: Cubic Corp., Electrotape Div., San Diego, California 92123. DEPT. E.-III

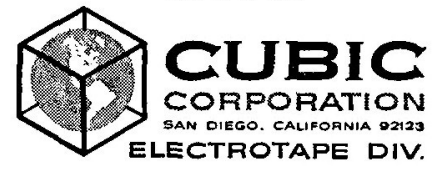




\section{The Institute of Navigation}

\section{INSTITUTE PUBLICATIONS}

\section{The Use of Radar at Sea}

A Handbook on Marine Radar. (Hollis \& Carter, 45s.)

\section{Observational Errors}

An elementary account of the ideas behind the statistical theory of errors, by E. W. Anderson \& J. B. Parker. (John Murray, 5s.)

\section{The Geometrical Seaman}

An illustrated work on early navigational instruments, by E. G. R. Taylor \& M. W. Richey. (Hollis \& Carter, 30s.)

\section{The Mathematical Practitioners of Tudor and Stuart England \\ by E. G. R. Taylor. (Cambridge University Press, 55 s.)}

An account of the ideas, instruments and methods in navigation and surveying between 1485 and 1715 with lists of the mathematical practitioners with biographical notes and details of their work.

\section{The Mathematical Practitioners of Hanoverian England}

by E. G. R. Taylor. (Cambridge University Press, 7os.) To be published shortly.

This book, a sequel to the earlier volume, takes the story up to $184^{\circ}$, by which time the independent mathematical practitioner had virtually disappeared, absorbed into the large firm or organization as a consequence of industrial and social change.

\section{Journal Index}

$$
\begin{aligned}
& \text { Vols. I- } 5, \text { 1948-63. (I os.). } \\
& \text { from The Institute of Navigation } \\
& \text { I Kensington Gore, London } \mathrm{SW}_{7}
\end{aligned}
$$




\section{Authoritative Sailing-Ship Books}

\section{Coolie Ships and Oil Sailers}

This book is a record of two special phases of sea life in Sailing Ships

190 pages $97^{\prime \prime} \times 7 t^{\prime \prime} 56$ illustrations

30/- (per post 33/-)

\section{The Colonial Clippers}

The Great Wooden Ships of the Blackwall and other lines

400 Pages $97^{\prime \prime} \times 7 t^{\prime \prime} 81$ Illustrations, 4 Plans

$36 /-$ (per post $39 / \cdot$ )

\section{The Nitrate Clippers}

The remarkable story with lovely reproductions of photographs

172 Pages $9 z^{\prime \prime} \times 7 t^{\prime \prime} 48$ Mlustrations

25/- (per post 28/-)

\section{The Log of the "Cutty Sark"}

The most authentic work, compiled from her $\log$ books and captain's abstracts

344 Pages $94^{\circ} \times 7 t^{\circ} 52$ Illustrations, 9 Plans

36/- (per post 39/-)

\section{The Last of the Windjammers}

Vol. I. The Sailing Ships of the Seventies-Eighties

535 Pages $94^{\prime \prime} \times 71^{\prime \prime} 126$ Illustrations, 17 Plans

$50 / \cdot($ per post 53/3)

Vol. II. The Deep-Water Sailing Ships, 1888-1928

470 Pages $9 t^{\prime \prime} \times 7 t^{\prime \prime} 174$ Illustrations, 17 Plans

50/- (per post 53/3)

BY BASIL LUBBOCK

All Lubbock's work is the product of original and comprehensive research.

These books are recommended without reserve to the student of the salling-ship

\section{Sail Training and Cadet Ships}

This Magnificent Volume is a most complete record

366 Pages $9 z^{\prime \prime} \times 7 t^{\prime \prime} 132$ Illustrations, 45 Folding Plans

$60 /-$ (per post 63/3)

\section{Deep-Water Sail}

For all Students of Sail and lovers of the Windjammer

387 Pages $9 t^{\prime \prime} \times 7 t$ Orer 200 Illustrations, 28 Plates

Plank-on-Frame Models and Scale Masting and Rigging

Vol. I. 34/- (per post 35/4) Vol. II. 34/- (per post 35/4)

By HAROLD A. UNDERHILL

A leading authority on Sail and Ship Modelling

\section{The Convict Ships 1787-1868}

This first complete record opens up a new field of maritime history

369 Pages $97^{\prime \prime} \times 64^{\prime \prime} 20$ Illustrations

$$
\text { BY CHARLES BATESON }
$$




\section{INTRODUCING}

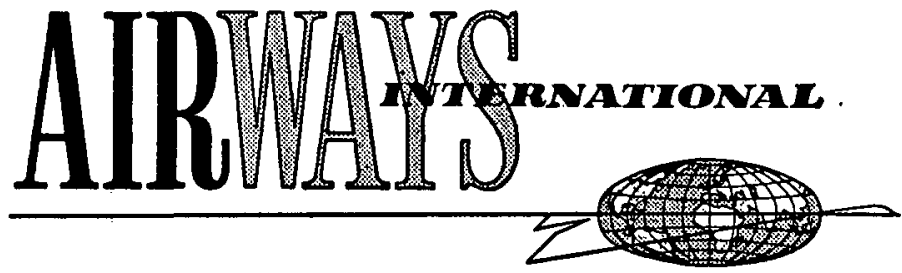

\section{A NEW JOURNAL in the} international field of airline and airport, engineering, supplies, services and equipment...

... established 1964 - bi-monthly - supplying a comprehensive coverage of its field. Contributors are acknowledged experts and their feature articles are designed to entertain as well as to inform. These articles are supplemented in each issue with pages of considered discussion of important matters in international air -transport, factual information, and regular features, to ensure the fullest readership value.

Regular features include : air transport news ; pictorial and diagrammatic presentations of aircraft, aircraft systems and flight aids ; personalia ; new equipment ; air book reviews ; events and meetings, etc. Summaries of feature articles 5s. Od. per copy, printed in French, German and Spanish.

30s. Od. per annum.

Published by
AIR
WORL
RLD
LIMITED
John Adam House, 17/19 John Adam Street, London, W.C.2.

An Industrial Newspapers publication 


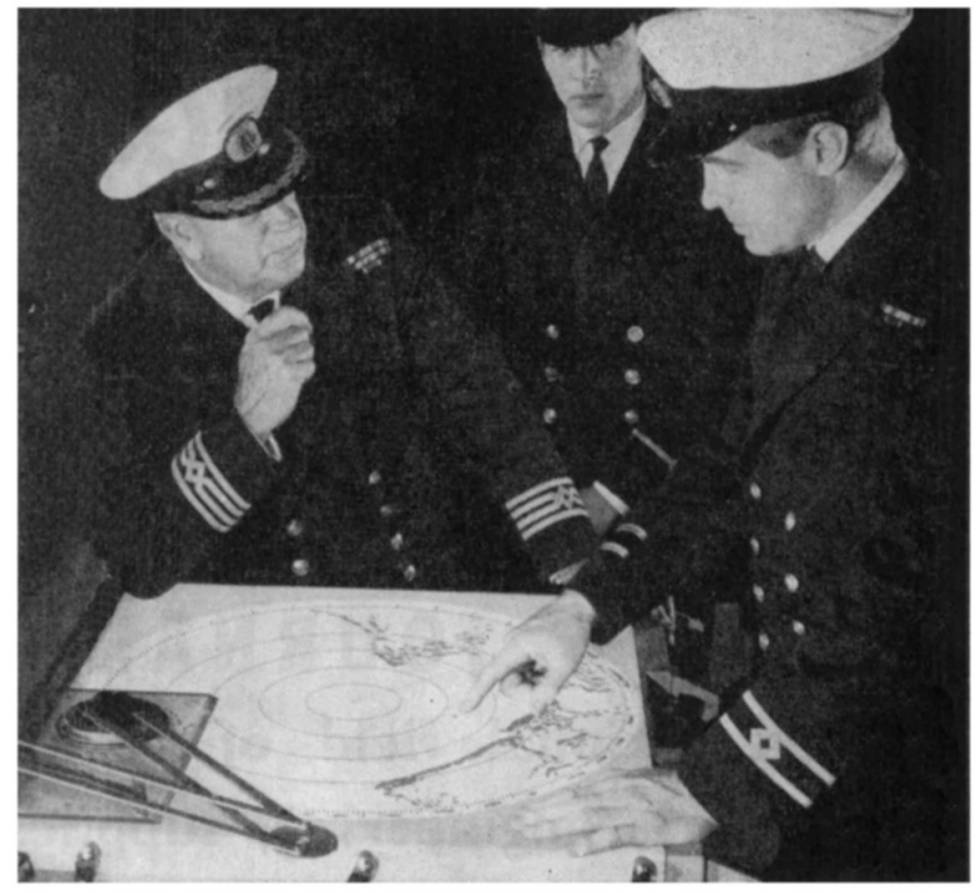

\section{Kelvin Hughes Pholoplot Radar}

In this equipment the conventional rotating radar trace and P.P.I. is superseded by a bright stable radar picture on which all echoes on all bearings are displayed simultaneously. The screen, 24 inches in diameter, is horizontal and covered with tracing paper on which target speeds and courses can be plotted directly. Targets are depicted in black against a white background, and the picture can be studied by several observers at the same time, both in daylight and at night, without resorting to a visor or hood. True plot or relative motion displays can be selected.

The radar information is first displayed in the normal way on a $3 \frac{1}{2}$-inch cathode ray tube. This display is then automatically photographed on special $\mathrm{I} 6 \mathrm{~mm}$ film, processed in a few seconds and projected on to the underside of a translucent screen. The time interval between successively projected pictures can be set at 15 seconds, three minutes or six minutes, according to plotting requirements. When the longer time intervals are used successive radar paints of moving targets become integrated over the selected period. They are then automatically shown on the display as lines of varying length and direction, indicating the track and distance travelled.

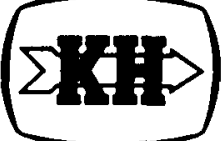

\section{KELVIN HUGHES}




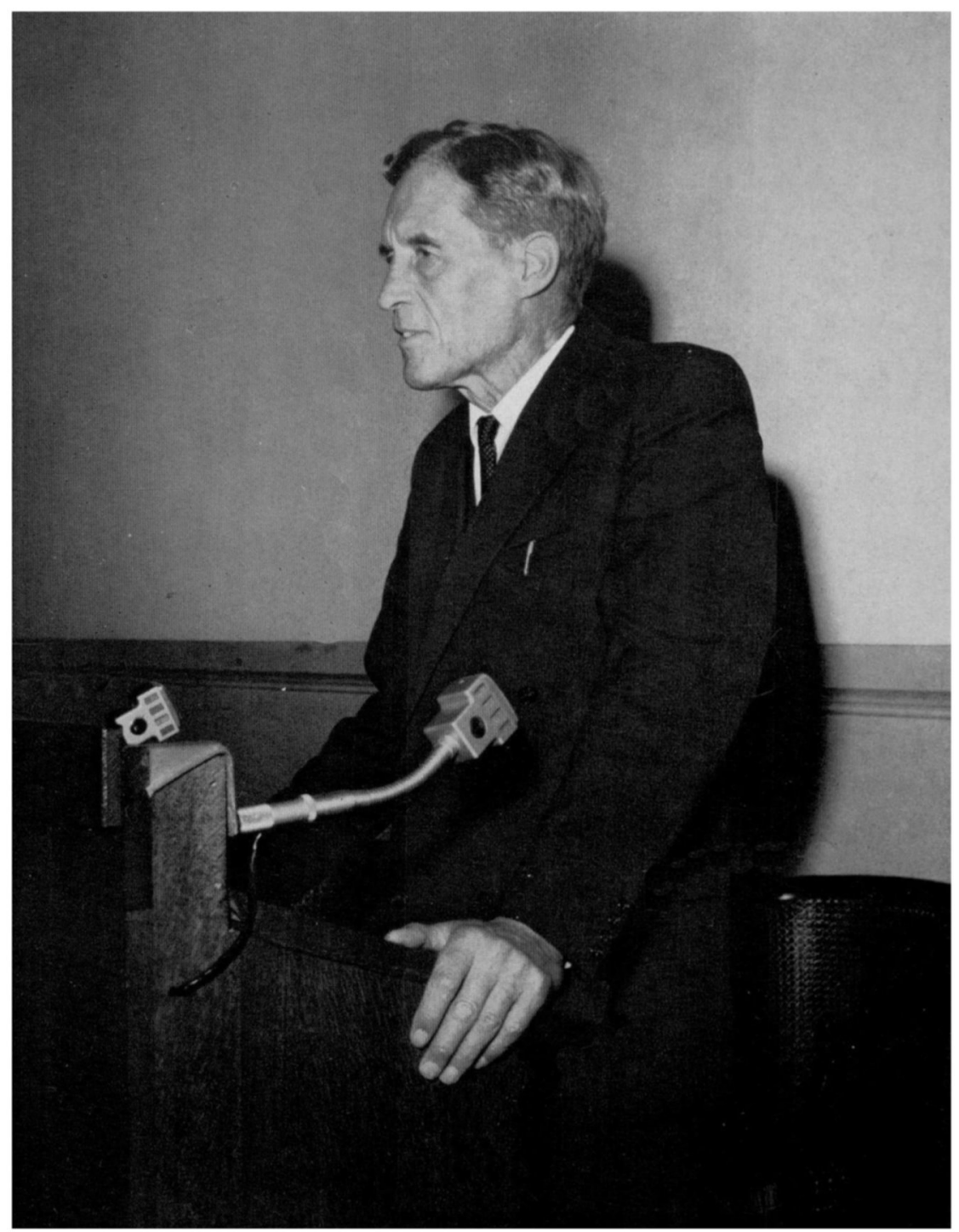

Professor P. M. S. Blackett, C.H., P.R.S., presenting the fourth Duke of Edinburgh's lecture to the Institute 